\title{
Allusions to Ancient Indian Mathematical Sciences in an Early Eighth Century Chinese Compilation by Gautama Siddha
}

\author{
Vijaya J Deshpande* \\ (Received 04 December 2014; revised 20 April 2015)
}

\begin{abstract}
Gautama Siddha belonged to one of the three prominent Indian families of expert-astronomers settled in China during Tang dynasty (618-906 AD). Members of this family held important positions in the successive astronomical bureaus of Tang dynasty. Gautama, once President of the bureau, was assigned the task of writing down a compendium Datang Kaiyuan Zhanjing (大唐開元占經) since he was very well acquainted with both systems, Chinese and Indian. He devoted one chapter out of hundred and twenty altogether, to Indian calendar-making method, popularly known as the Jiuzhili or Navagraha method.

At the outset Gautama explained the decimal notation system as employed in arithmetical operations in India at that time. He recorded symbols for numbers one to nine and also zero. He went on to explain the division of earth's orbit into 360 degrees as against more than 365 in the Chinese system and further proposed algorithms for calendar making and prediction of lunar and solar eclipses. Trigonometric functions were also officially introduced to China through this work.
\end{abstract}

Key words: Ancient Indian astronomy, Calendar making, Eclipse-equinox prediction, Gautama Siddha, Jiuzhili, Navagraha, Siddhāntic astronomy, Tang China

\section{INTRODUCTION}

Study of the skies or 'the heavens' was a topic of great interest even to the ancients. It was useful in navigation at night to begin with. Monthly rotation of the moon and yearly rotation of the earth were studied to predict seasons, making accurate calculations of the calendar day and predicting celestial events like equinoxes and eclipses that sometimes had religious significance. Ancients also observed and recorded relative position of the planets as against the sun and distant constellations, to understand their motion. Every ancient culture developed their individual system of celestial observation, recording, calculations and prediction based on their indigenous celestial map with characteristic nomenclature for stars, planets and constellations. Yet, transmission of ideas and techniques were not infrequent. Babylonian, Greek, Arabian cultures successively influenced both Indian and Chinese astronomy.

Likewise Indian astronomy substantially influenced both Arabian and Chinese astronomy during medieval period.

As Buddhism established itself in China, alongside Buddhist monks, experts of other fields like astronomy, medicine etc often visited the Chinese capital, especially during Tang dynasty. Three Indian families of expert astronomers are mentioned in Chinese historical records. Among them one 'Gautama' family was outstanding in the positions they held in court and their scholarly work in the field of making new calendar system, writing/compiling books. They advised the ruler in astrological matters too. They were highly

\footnotetext{
*76/37A, Erandawana, Pune, 411004; Email: vijaya.deshpande@gmail.com
} 
Table 1. Approximate parallels to Nakṣatras are listed below

\begin{tabular}{|c|c|c|c|}
\hline Rohin̄ī 畢 Bì & Krttikā 昂 Mǎo & Bharaṇī 胃 Wèi & Aśvin̄̄ 婁 Lóu \\
\hline Pusya 鬼 Gŭ & Punarvasu 井 Jing & $\bar{A} r d r \bar{a}$ 參 Shēn & Mrgaśiras 觜 Z $\bar{l}$ \\
\hline Uttara-Phālgunī 翼 $Y \grave{l}$ & Pūrva-Phālgunī 張 Zhang & Maghā 星 Xīng & Aśleṣa 柳 Liǔ \\
\hline Viśākhā 氏 $D \breve{\imath}$ & Svāti 圥 Kàng & Citrāa角Jiǎo & Hasta 軨, Zhěn \\
\hline$P \bar{u} r v a-A s \bar{a} d h a$ 箕 $J \bar{\imath}$ & Mūla 尾Wěi & Jyesthā 心 Xīn & Anurādha 房 Fáng \\
\hline Dhanișthā 盧 $X \bar{u}$ & Śravana 女 $N \ddot{u}$ & Abhijit 牛 Niú & Uttara-Așādhā 斗 Dǒu \\
\hline Revatī 奎 Kui & Uttarābhadrapadā 壁 $B i$ & Purvābhadrapadā 室 Shi & Śatatārakāe杘Wēi \\
\hline
\end{tabular}

respected for their mastery over both Indian and Chinese theories and techniques, and overall contribution they made in transmitting ancient Indian astronomical-mathematical knowledge into China. This article studies contribution by Gautama Siddha in some detail.

\section{AnCient ASTRonomy - IndiAn AND Chinese}

Ancient Chinese and ancient Indians both had their separate astronomical theories and practices that were in use long before they developed close contacts through Buddhism from second century AD onwards. These systems were largely similar since they both were studying identical celestial phenomena. Variations were due to dissimilar assumptions and other geographic and cultural factors.

A naksatra or a lunar mansion in Chinese is the group of stars the moon moves through in twenty four hours. Since the moon revolves round the earth in about twenty eight days, number of naksatras or mansions is also the same. ${ }^{1}$ In fact, apart from the number twenty eight, all other factors are different e.g. number of stars in each nakșatra/mansion are different since they depend upon the position of the observer and therefore are defined in a different way in each culture. Again, when the stars in the constellation are not exactly alike, their overall shape, chief star in that constellation differs too. ${ }^{2}$

The twenty-eight mansions 二十八宿 of Chinese astronomy are divided into four groups of seven each referred to as East or Spring; South or Summer; West or Autumn; and North or Winter. Chinese zodiac is tropical i.e. it relies on sun's position in a particular constellation, and hence mansions are related to specific seasons. Furthermore, the beginning of the year does not change with precession of equinoxes but remains fixed since it is related to particular lunar mansion i.e. a distant constellation. Thus Chinese year begins when the sun enters the lunar mansion jiao 角, which is the first mansion in the section 'east' of the lunar mansions. Naksatra Citra which means bright, clear or variegated corresponds to Chinese lunar mansion jiao which means 'horn'. Both correspond to the star spica in western astronomy. Here correspondence is as regards location which is measured as longitude with respect to the equatorial plane.

\footnotetext{
1 The number was revised to 27 in later Indian works from $5 / 6^{\text {th }}$ century AD onwards. Nakśatra 'Abhijit' was dropped since it was not necessary. The division of the zodiac in 27 Nakśatras was accepted to account for the period of 27.32 days taken by the moon to complete one rotation through the zodiac i.e. 360 degrees.

2 Niu weixing. (1997/98), p119-129

Sütra on Mañjuśrī Bodhisattva and the Sage's Teaching on Auspicious and Inauspicious Times, Days, Good and Evil Constellations and Luminaries 文殊師利菩薩及諸仙所說吉区時日善惡宿曜經, translated by Amoghavajra (705-774 AD) in 759 and revised in 764 by disciple Yang Jing Feng 楊景風 under his master's guidance.
} 
On the contrary, a major difference lay in calculating angles, since Indians divided the celestial orbit in 360 degrees whereas the Chinese into little more than 365 which is based on their assumption that the sun moves one degree per calendar day of twenty four hours. They divided the whole zodiac by number 365.25 hence their single smallest unit is smaller than a degree. ${ }^{3}$

\section{Ancient Indian Astronomy in Chinese Buddhist works}

Earliest indication of the entry of Indian astronomy is found in Buddhist canonical works. Ideas related to cosmology, constellations, the sun, the moon, planets; also names and categories of months like lunar, solar, intercalary months, changes in the lengths of day and night, noon shadow method for determining latitude of a place etc. are recorded in these works. ${ }^{4}$

Following three sutras allude to the noon shadow method for determining latitude of a place. $^{5}$

Modengjia jing, Mātangasūtra 摩登伽經 (TT 1300) the Chinese translation of Śärdūlakarṇaavadāna, translated into Chinese in $230 \mathrm{AD}$,

Fo shuo shi fei shi jing 佛說時非時經(TT794) When time was non-time sūtra as told by Buddha

Dafang deng daji jing 大方等大集經 (TT 397) Mahāvaipulya mahāsamghāta sūtra

Siddhāñtic astronomy appeared in later Buddhist sūtras. Buddhist sūtra Brahmahorānavagraha written around $751 \mathrm{AD}$, alluded to navagraha defined by the Indian tradition, the nine heavenly bodies as 九執 Jiu zhi, the nine grahas, "seizers" or upholders, also written as Jiu yao九曜 or nine luminaries or planets.

The nine luminaries mentioned are: Áditya - the sun, 月 Sōma - the moon, five planets are- 火星 Angāraka - Mars, 水 Budha - Mercury, 木 Brhaspati - Jupiter, 金 Śukra - Venus, and 土. Sanaiścara - Saturn; also 羅睺 Louhou - Rāhu, and 計都 Jidu - Ketu, the demons that were supposed to cause eclipses. ${ }^{6}$

\section{Ancient Indian Astronomy in Chinese Historical Records}

Several allusions to ancient Indian astronomy, visiting Indian astronomers and their skills are found in Chinese historical records too. Titles of works related to mathematics and astronomy were also included in the Polomen 婆羅門 or Brahmin books listed in the bibliography of Sui dynasty (581-618 AD). These books are no more extant though. Their titles mention Jivaka, Nagarjuna, Brahmins or western sages as their authors suggesting their Indian connection. Among these, one by the name Polomen tian wen jing 婆羅門天文經, was probably related to astronomy and calendar science.

Later in the year 759 AD Amoghavajra, a well-known Tantrik author and translator of Buddhist canonical works, wrote Xiu yao jing 宿曜經 i.e. 'Lunar mansion and planet sūtra'. A commentary to this work by Yang Jingfeng mentioned the three Indian schools of astronomy in following words.

\footnotetext{
3 Ho Pengyoke (1985)

4 "Four definitions of month are given in Volume 48 of Great Treatise on the Perfection of Wisdom namely "Solar Month", "Karma Month", "Lunation Month", "Naksatra Month". Therein, "Solar Month" is one-twelfth the length of the tropical year, "Karma Month" is an ideal year (360 days as an ideal year), "Lunation Month" is namely the synodic month and "Nakșatra Month" is the sidereal month'. See Encyclopedia of India-China cultural contacts, MaXposure Media Group, New Delhi, 2014, part $1, \mathrm{p} 74$

5 Niu weixing - (1997/98), p199-129

Also see, Niu Weixing and Jiang xiaoyun, (1998).

6 Niu Weixing (2005) p329.
} 


\begin{abstract}
'Those who wish to know the positions of the five planets adopt Indian calendrical methods. One can thus predict what $h \operatorname{siu}^{7}$ (a planet will be traversing). So we have the three clans of Indian calendar experts, 迦葉 Chia yeh (Jia ye Kāsyapa), 翟曇 Chhu than ( Qu tan Gautama) and 傿摩羅 Chu mo lo (Jiu mo lo Kumāra), all of them hold office at the Bureau of Astronomy. But now most use is made of the calendrical methods of Master Chhu than chuan (Qutan zhuan) ${ }^{8}$ together with his Great Art'?
\end{abstract}

Here the author states that positions of five planets can be determined using Indian methods. Probably they were part of earlier calendars 經緯歷 Jingweili and 光宅歷 Guangzaili composed by Gautama Rahula, father of Gautama Siddha or in the methods taught by experts of other clans viz. Kaśyapa and Kumāra.

Also, Xintangshu, New History of Tang dynasty $\left(10^{\text {th }}\right.$ century $\left.\mathrm{AD}\right)$ records that Temolo, an Indian transmitted the method of solar eclipse prediction. ${ }^{10}$

In order to translate Buddhist works related to astronomy and astrology into Chinese and to express Indian ideas correctly, new terminology was developed in Chinese. It was formulated either by translating Sanskrit words into Chinese or transliterating them using Chinese characters with similar sounds e.g. 阿濕昆爾A shi bi ni for aśvinī, 阿失麗沙 A shi li sha for Aśleșa and 阿奴邏陀 A nu luo tuo for Anurādhā. This terminology changed with time as Gautama Siddha specifically mentioned in his work.

In the sub-section no. 4 while calculating the mean longitude of the sun, Gautama Siddha explains the division of degrees in Indian method as sixty minutes of fen making one degree and thirty degrees making one zodiacal sign called hsiang and further that, signs filled to twelve should be cancelled. (Naturally, since they complete one circle). Gautama writes,

'The hsiang is called loshih ( $r \bar{a} s \hat{\imath})$ in

Sanskrit, which means collection.

Formerly it was translated as tz'u, and now hsiang is adopted.'

We can see here that Chinese astronomers before Gautama's time itself replaced the transliterated word loshi to its Chinese counterpart hsiang.

Again, in the sub-section no. 7, while calculating the anomaly of the moon 月藏 Gautama Siddha states,

$$
\begin{aligned}
& \text { 'Formerly yuehts'an (yuecang) was } \\
& \text { sometimes translated as yueh-sun-i-shuai } \\
& \text { 月損罝率 (candra-rṇa-dhana in } \\
& \text { Sanskit)' }
\end{aligned}
$$

When ideas or substances came from outside, related terminology was transmitted too. As new substances or ideas became familiar their foreign sounding names were dropped for more homogeneous terms. This is observed even in other disciplines like chemistry, alchemy and medicine. $^{12}$

\section{Gautama Clan of Astronomers}

The long tradition of having Indian scholar-astronomers in prominent positions in the Tang court began in mid sixth century AD and Jiaye xiaowei was probably the first among them. Jiaye or Kāśyapa, Jiumolo or Kumāra and Qudan

\footnotetext{
7 宿 Hsiu or Xiu in Pinyin or the modern system of transliteration means '(lunar) mansion'.

8 Son of Gautama Siddha

9 Xiuyao jing p 350, see Sen Tansen (1995) p197

${ }_{10}$ Yabuuti, K. (1979) p2

${ }^{11}$ Yabuuti, K. (1979) p 18 (Translation by Yabuuti K.)

${ }^{12}$ Nao sha for ammonium chloride or Sal ammoniac was written with different characters in succeeding periods which suggested that it was a transliterated word from some foreign language. The word was in fact derived from Sanskrit Navasāra. It was later changed to Lu hua an 氯化銨 or Muriate of ammonia.
} 
or Gautama, these three were major astronomical schools of Indian origin at that time. Qudan xida or Gautama Siddha belonged to the Gautama clan settled in China. ${ }^{13}$ Four/five generations of this clan were high officers in astronomical bureaus of Tang dynasty. When Gautama family's tomb was excavated in Chang an in the year 1977, inscriptions therein provided more information about the clan.

Gautama family was originally from Banares. One named Gautama yi went to China sometime in the sixth century. He worked as a translator of Buddhist classics. His son Gautama Rāhula 翟量羅 was the director of astronomy between 627 to 649 AD. He compiled two calendars viz. 經緯歷 Jingweili and 光宅歷 Guangzaili. As the family settled down in China they married Chinese women so later generations are not mentioned as 'Indian' in Chinese records. ${ }^{14}$

Gautama Siddha 翟量悉達 was born sometime after $650 \mathrm{AD}$. He was the head of the Bureau of Astronomy from 712 to 718 AD. Between 712 and $713 \mathrm{AD}$ he was in charge of repairing the armillary sphere. In $718 \mathrm{AD}$ he translated the Navagraha Siddhānta - Jiuzhili into Chinese. Being well acquainted with Chinese astronomical development till the time, he was given the task of compiling astronomical works. Gautama Siddha compiled a book named 大唐 開元占經 Datang Kaiyuan Zhanjing - 'The Great Tang Treatise on Astrology of the Kaiyuan Era' between the years 718 and 728 AD. He included all earlier rare texts of Chinese astronomy in this compilation thus making the otherwise extinct works available to posterity. For this reason, he is a highly respected figure in the History of Chinese astronomy.

Kaiyuan zhanjing devoted chapter 104 (hereafter KYZJ-104) to the so-called navagraha or jiuzhi 九執 method of calendar making. It was initially introduced into China through the Mātanigasūtra translated in third century AD. These navagraha or 'Nine upholders' refer to the sun, the moon, five planets and Rāhu and Ketu that were the terms given to the two nodes, ascending and descending respective of the moon. Scholars believe the contents of (KYZJ-104) as derived from, and not a direct translation of, famous sixth/seventh century Indian astronomical works Pañcasiddhāntikā by Varāhamihira and Khandakhādyaka of Brahmagupta of AD 575 and 665 respectively. ${ }^{15}$

Gautama Siddha wrote advanced algorithms in KYZJ-104 for calculations for predicting various astronomical events. Jiuzhili or the navagraha system did not get much popularity though. Knowing its importance the manuscript was secretly preserved. Therefore it was forgotten over a long period till accidentally in 1616 AD Cheng Mingshan 程明善 discovered the manuscript inside the stomach of a Buddha statue, most probably hidden there for safe keeping by some unknown Buddhist monk-scholar. ${ }^{16}$

\footnotetext{
Tang and early Song names of eye disease pterygium are Nurou panjing 努肉攀睛 spoilt flesh spreading over the eye', and Nurou qinjingwaizhang i.e. 幒肉侵睛外障 ‘The external obstacle due to the spoilt flesh invading the eye'. They appear to be derived from the Sanskrit term Prastāri arma - A spreading (over the eye) spoilt flesh. This was the time when there occurred major transmission of ophthalmic ideas to China from India. Pre-Tang name for the same disease was Xi rou or polypus in general. In modern terminology, pterygium is now called Yizhuang nurou 毉裝㐐肉 or Wing-shaped spoilt flesh. This name is derived from the English name of the disease 'pterygium' which means 'wing-shaped'. It is in turn derived from Greek pterygion meaning 'wing'.

${ }^{13}$ Sen Tansen (1995)

${ }^{14}$ Jean-Claude Martzloff- Le Calendrier Chinois

${ }^{15}$ Li Hui and Niu Weixing(2014) (2010)

${ }^{16}$ Yabuuti, K. (1979) p 9
} 


\subsection{The 'zero' symbol and decimal place value system}

In Indian scientific literature from the sixth century AD onwards one frequently comes across the 'zero' symbol and its application in the decimal place value. In the year $498 \mathrm{AD}$, when Āryabhatta wrote his Áryabhatiyam, he introduced the decimal place value system. Even before that time a Jain work Lokavibhāga of $458 \mathrm{AD}$ referred to it. In China, however, both these concepts were unknown at the time of writing of KYZJ. The KYZJ -104 clearly mentioned both, the symbol of zero and its use in decimal value system for the first time. The text elaborated the new concepts in following words.

等字法. 样一字二字三字四字五字六字七字八字九字点右天䇥等法, 有上件九个字乘除, 其字皆一举礼而成凡数至十进入前位每空位处佰安一点 有间咸记, 无由轧错, 运等便眼趁须, 先及历度

'Method of the 'Counting symbols': symbol for 1 - for 2 - for 3 - for 4 - for 5 for 6 - for 7 - for 8 - for 9 and a dot. On the right (i.e. aforesaid) is Indian counting method. Using the above nine symbols, multiplication and divisions are carried. All these characters are single stroked, and are written cursively. While counting when the number reaches ten then it is entered in the front (row). In each vacant place is then placed one dot. In this way there is a mark/symbol in each place so there cannot be any error. The calculation is necessarily easy to the eye, so it is (we have described it) before the calendrical methods.'

Although, perhaps the symbols for the numbers were written by the original author Gautama Siddha, they were dropped by successive copyists and now we have only the mention of them in KYZJ that is preserved in a $18^{\text {th }}$ century compilation that is oldest available source of this work now. ${ }^{17}$

KYZJ is available separately too in new editions. ${ }^{18}$

\footnotetext{
${ }^{17}$ Here is the page from 四庫全書 Siku quanshu, a eighteenth century collection which contains KYZJ. The column second from left keeps the places of symbols blank. See the page below. It actually says 'character/symbol (for) 1, character (for) 2, and so on, without actually writing symbols. It is followed by the character in Chinese for 'dot' which is dian 點 or in the simplified version in modern compilations dian 点 as quoted in the passage above.
}

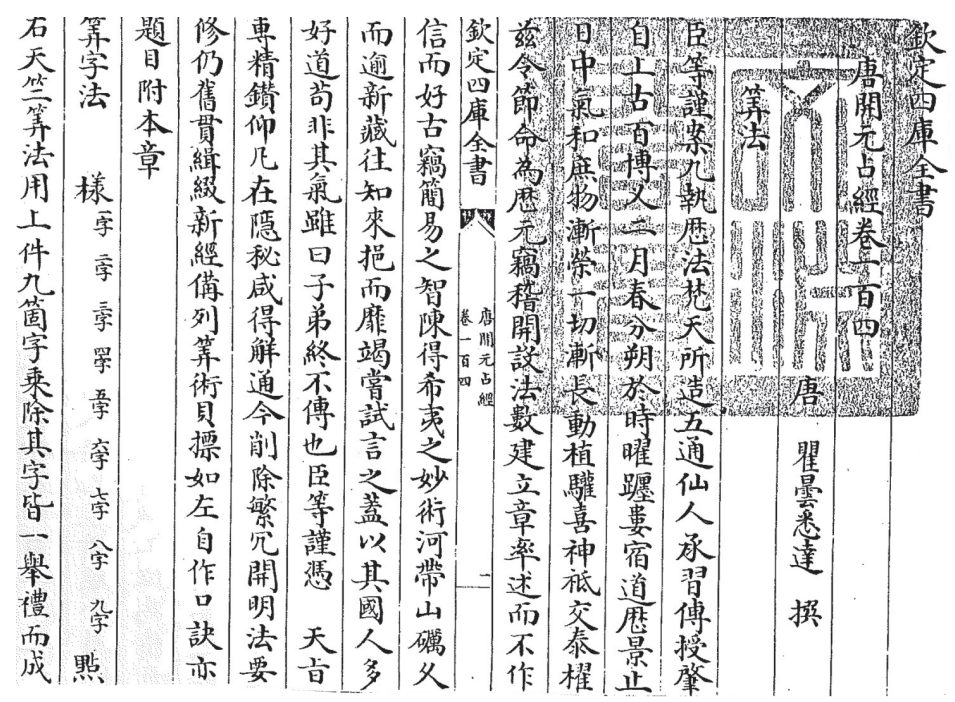

Fig. 1 See Siku Quanshu 四庫全書 Wen yuan ge si ku quan shu dian zi ban. [Catalog] [electronic resource] / Di zhi wen hua chu ban you xian gong si. 文淵閣四庫全書電子版. [Catalog] [electronic resource] 迪志文化出版有限公司. Hong Kong [1999?]

${ }^{18}$ Kai yuan zhan jing (2012) 
Other Chinese Buddhist works written around eighth century that refer to Indian numerals may give an idea as to how Gautama Siddha might have had written the numbers.

\section{Later generations of the Gautama FAMILY AND D AYANLI CONTROVERSY}

Yi xing 行 (683-727 AD), a contemporary of Gautma Siddha, was a mathematician, astronomer and also a translator-commentator of Buddhist canonical works. He was in charge of the terrestrial astronomical board and under his direction was carried out the gigantic task of measuring shadow lengths and longitude of pole star at thirteen places between latitude 29 to 52 degrees North. These observations were used in a variety of astronomical calculations and eventually in writing a new calendar 大衍历 Dayanli. He created an armillary sphere in Chang an. Yi xing was the most prominent Buddhist monk of the time.

Gautama Siddha's son, Gautama Duan (712-776 AD) was a scholar astronomer as well as a soldier. He later held the office of Vice Director of the bureau of astronomy as the post was called in the Tang. Gautama Duan criticized Dayanli calendar made by Yi xing in 727 AD after the latter's death, pointing out that portions from Jiuzhili calendar were incorporated in Dayanli. He accused Yi xing of plagiarism. Since Yi xing was highly respected, and also that Gautama Duan's astrological predictions sometimes failed, he was banished from the court and the kingdom. Later, after the regime change he was reinstated and many honors were conferred upon him.

Some scholars are of the opinion that certain tangent tables documented by Yi xing were most probably an outcome of calculations made using sine tables method stated in Jiuzhili than actual observations. ${ }^{19}$ Again, some other scholars do not agree with this but propose an alternative method that Yi xing might have used. In a nutshell, there exists controversy regarding the extent to which Indian methods/theories were incorporated in Dayanli but all agree that although Yixing used traditional Chinese methods in his calendar making, he was acquainted with Indians theories and he made use of them too.

Before Yixing there were astronomers like Cao Shikui of mid-Tang dynasty who developed their own methods and algorithms to calculate astronomical events. In his Futianli calendar Cao Shikui used the terms or concepts like Louhou $R \bar{a} h u$ and Jidu - Ketu but stuck to the measure of Sun's rotation as one degree a day, again an integration of two systems.

Yabuuti Kiyosi translated KYZJ - 104 i.e. Jiuzhili or the Navagraha calendar into English. He wrote an article based on his studies in the year $1963 .{ }^{20}$ Later in the year 1979 he revised the translation with Michio Yano and published an article that included a commentary to Yabuuti's translations by Yano who is an expert of ancient Indian astronomy. ${ }^{21}$ Yano explained Gautama Siddha's algorithms in terms of Siddhāñtic astronomical methods of calculations, simultaneously elucidating parallel terms from Sanskrit. Together Yabuuti and Yano translated and discussed all 37 sub-sections of the KYZJ-104 which are,

1. Numerals

2. Degrees in Astronomical System

3. Chapter on the chijih 积日(jiri), sum of days from the epoch, dyugana or ahargana in Sanskrit and the hsiaoyu 小馀 (xiaoyu), its fraction

4. Chapter on the Calculation of the chungjih 中日 (zhongri) mean latitude of the sun madhyasūrya in Sanskrit

\footnotetext{
${ }^{19}$ Cullen, Christopher (1982)

${ }^{20}$ Yabuuti, Kiyosi. (1963)

${ }^{21}$ Yabuuti, K.(1979)
} 
5. Chapter on the Calculation of the chungyueh 中月 (zhongyue), mean longitude of the moon, madhyacañdra

6. Chapter on the Calculation of the kaoyueh 高月 (gaоyue), longitude of the lunar apogee, cañdra-ucca in Sanskrit

7. Chapter on the Calculation of the yuehtsang 月藏 (yuecang), anomaly of the moon, cañdrakendra in Sanskrit

8. Chapter on the Calculation of the jihtsan 日藏 (jicang), anomaly of the sun, süryakendra in Sanskrit

9. Chapter on the Calculation of the tingjih 定日 (dingri), true longitude of the sun in Sanskrit

10. Chapter on the Calculation of the tingyueh 定月 (dingyue), true longitude of the moon, sphutacandra in Sanskrit

11. Chapter on the Calculation of the Daytime and Night

12. Chapter on the Computation of yuehyu 月域 (yueyu), moon's boundary i.e. true daily motion of the moon

13. Chapter on the Calculation of the jihyu 日域 (riyu), difference between the daily motion of the moon and the sun

14. Chapter on the Calculation of the hsio-ko 小刻 (xiaoke), nakșatra-kāla in Sanskrit: a time interval since moon's entrance into the current naksatra to its present position at midnight

15. Chapter on the Calculation of the hsiutuan 宿断 (suduan), naksatra-cutting i.e. time when moon enters the nakșatra, naksatra-ccheda in Sanskrit

16. Chapter on the Calculation of the chiehko 节刻 (jieke), time of joint i.e. time interval between syzygy and midnight before and after, parvakāla in Sanskrit

17. Chapter on the Calculation of the chiehtuan 节断(jieduan), joint cutting, parva-ccheda in Sanskrit
18. Chapter on the Calculation of the chunfen 均分 (junfen), longitude of the moon and the sun at syzygy, samalipta in Sanskrit

19. Chapter on the Calculation of the ahsiu 阿修 (axiu), the moon's node, asura in Sanskrit

20. Chapter on the Calculation of the chienliang$f u$ 间量府 (jianliang $f u$ ), longitude of an eclipsed body counted from moon's node

21. Chapter on the Calculation of the yuehchienliang-ming 月间量命 (yuejianliangming) half the cord of the chienliang-fu 间量府 (jianliangfu) i.e. sine table

22. Method on the calculation of the yuehchienliang 月间量 (yuejianliang), moon's latitude

23. Method on the calculation of the yuehliang 月量 (yueliang), apparent diameter of the moon

24. Method on the calculation of the ahsiu-liang 阿修量 (axiuliang), diameter of the earth's shadow

25. Method on the calculation of the chuanwei 全位 (quanwei) or panwei 牛位 (banwei) of the ahsiu 阿修 (axiu) and the moon (sum of the diameters of the earth's shadow and of the moon

26. Method on the calculation of the Duration of a (lunar) Eclipse

27. Method on the calculation of the yueh-kuei 月規 (yuegui), moon's disc i.e. magnitude of a lunar eclipse

28. Method on the calculation of the shihshen 蝕㝟( shishen), middle of eclipses i.e. vimarda in Sanskrit

29. Method on the calculation of the shihhsiang 蝕行 (shixing), direction of the obscuration

30. Method on the calculation of the jih-liang 日量(jiliang), apparent diameter of the sun 
31. Method on the calculation of the Solar Eclipses

32. Method on the calculation of the jihshangsussu 日上虛驱 (jishangxusi)

33. Method on the calculation of the chiehtuancho 节段刻 (jieduanke), the ecliptic point on the eastern horizon at the time of a solar eclipse, parvakālalagna in Sanskrit

34. Method on the calculating the jih-chienliangming 日间量命 (jijianliangming)

35. Method on the calculation of houming 后命 (houming)

36. Method on the calculation of the jih-chienliang 日间量 (jijianliang), moon's parallax in latitude

37. Calculation of a solar eclipse

\section{Contribution of Gautama Siddha to Chinese astronomy}

Gautama Siddha must have faced enormous difficulties when he compiled KYZJ and particularly when he wrote the chapter on Jiuzhili. It was not an easy or straightforward task to write this chapter for several reasons. For that matter, the task of translating Buddhist works in general into Chinese must have been challenging in itself. It either involved word to word translations, or in the case of scientific texts when basic concepts were unfamiliar to the Chinese, the author either explained or simplified them. While dealing with topics like astronomy and medicine, the writer who would be a subject expert as well as linguist just as Gautama Siddha was, essentially wrote a new book altogether. The outcome typically would be a simplified version of original Indian work and an integration of two systems to some extent.
An analogous phenomenon was observed when Nagarjuna's ophthalmic works were written in Chinese between ninth and twelfth century AD. Although these works are based on Suśrutasamhitā and Astāinghrdaya, they essentially depict an integration of ancient Indian and Chinese ophthalmology. 22

Following factors must have made the writing of KY-104 tricky.

1. Different methods for the division of circle into degrees

2. New concepts introduced e.g. trigonometric concepts and the sexagesimal system for division of degrees, i.e. a degree is divided into 60 minutes

3. Dissimilar epochs used in Chinese and Indian calculations $^{23}$

4. Sanskrit terminology unknown to the Chinese and its forever changing Chinese parallels as seen in section 4 .

5. Changing the standard latitudes to those of the Chinese capital Chang an for further calculations (see sub-section 11) ${ }^{24}$

6. Theoretical considerations behind the construction of these algorithms were difficult to comprehend for the Chinese since they knew neither language nor tradition,

All this must have made writing of KY104 very complex. Yet for the fact that predictions made on the basis of actual observations as done in the Chinese system were found to be more accurate than those using Indian methods, the foreign system was ignored; irrespective of the fact that they were based on genuine scientific theory. A paragraph from the New history of Tang dynasty quoted by Cullen (1982) makes the whole

\footnotetext{
${ }^{22}$ Deshpande Vijaya Jayant with Fan Ka Wai (2012),

Also see Deshpande Vijaya Jayant (1999), (2000)

23 - 'first day of the second month in the second year of Hsiench'ing reign period, March 20th of 657AD, Julian calendar') and Indian- March 20/21, 505 A.D. or Saka 427/428)

${ }^{24}$ Yabuuti, K.(1979) p25
} 
scenario apparent. ${ }^{25}$ Leaving aside the veracity of their judgment we surmise that Jiu zhi li was officially judged to be less precise and ignored.

Importance of the Indian system was acknowledged by certain Arab travelers in Tang China. Needham writes, 'Contemporaries such as Sulaimān al - Tājir recorded the impression that Indian astronomy was more advanced than the Chinese.' Sulaimān al - Tājir states, 'Physic and Philosophy are cultivated among the Indians, and the Chinese have some skill in medicine, hot irons or cauteries, they also have some smattering of astronomy; but therein the Indians surpass the Chinese. ${ }^{26}$

It was Yabuuti who recognized the true contribution of ancient Indian astronomy. Yano, Michio states, 'Indian astronomy represented by Jiuzhili was not highly regarded in China. Chinese records often refer to the Jiuzhili as a 'crude' calendar in comparison with Chinese calendars. ${ }^{27}$ Yabuuti, however, correctly pointed out importance of the very theoretical nature of Indian astronomy even though it was not very accurate from the practical point of view. For instance the decimal notation system with the symbol of zero, the sine function, spherical astronomy with graphical representation, and parallax computations for solar eclipses were all recorded in this book'. ${ }^{28}$ Yano further quotes Yabuuti Kiyosi, 'Such theoretical methods are far more advanced compared with the calendars in the Tang dynasty that used so called experimental methods, in other words, methods of induction exclusively from the ancient records. ${ }^{29}$

Li Hui summarized the contribution made by Siddhāñtic astronomy in following words,

'In terms of astronomical calculation, Jiuzhi Calendar, at least, introduces six western (Indian) astronomical elements to China:

1. $360^{\circ}$ circumference division

2. Counting method for 60 binary

3. Ecliptic coordinates system

4. Definition of distinctions between perigee and winter as well as between apogee and summer solstice

5. Method for calculating the visible diameter change of the Moon

6. Sine function calculation method and sinefunction table. ${ }^{30}$

\footnotetext{
${ }^{25}$ Cullen (1982), p 30-33)

The author quotes from Xin tang shu 新唐书 (New history of Tang dynasty of 1060 AD

'In the twenty-first year (of Kaiyuan era i.e. 733 AD) he (Qutan zhuan) memorialized jointly with Ch'en Hsuan-ching (Chen Xuan-jing) "The Ta Yen li (Da yan li) plagiarizes the Chiu Chih li (Jiu zhi li), and its methods are incomplete." A similar condemnation came from Nan-Kung Yueh (Nan-gong Yue), the Right Guardian of the Heir Apparent. The Imperial Clerk Li Lin and the Astronomer Royal Huan Chih-Kuei (Huan Zhigui) were then instructed to check the register of observations of the Imperial Observatory. It was found that the Ta yen li (Da yan li) was correct seven or eight times out of ten, the Lin te li ( Lin de li) three or four times, and the Chiu Chih li (Jiu zhi li) once or twice only. Thus Nan-Kung Yueh (Nan-gong Yue) and others were seen to be in the wrong, and the dispute was settled." Hsin T'ang Shu (Xin tang shu)(28A, 587). Again, a brief note on the Chiu Chih li (Jiu zhi li) follows the full description of the Ta yen li (Da yan li). It concludes, 'The methods of Chiu Chih li (Jiu zhi li) were overelaborate, and although they were sometimes fortuitously correct they could not be taken as standard. The terms and quantities employed were strange, and at first no one could make sense of them. Ch'en Hsuan-ching (Chen Xuan-jing) and others took advantage of this to deceive their contemporaries, saying that I-hsing (Yi xing) has plagiarized (the Jiu Zhi li) and that the methods (of Da yan li). This was nonsense." Hsin T'ang Shu (Xin tang shu) 28B:692).

${ }^{26}$ Needham Joseph, Wang Ling. (1959), p 203

Also see, Al-Sīrāfì, Abū Zayd \$asan ibn Yazīd, (1733)

${ }^{27}$ See FN 24 above.

${ }^{28}$ Yano Michio (2001)

${ }^{29}$ Yabuuti Kiyosi. (1944)
} 


\subsection{Planetary Motion}

The translated contents of Jiuzhi Calendar include the motions of the Sun and the Moon and calculations of magnitude and durations of lunar and solar eclipses, but are not related to planetary motion. ${ }^{31}$ Again, in an earlier quote an eight century author states that positions of five planets can be determined using Indian methods. These methods are not found in KY-104. To investigate whether they were part of earlier calendars Jingweili and Guangzaili will again make an interesting and worthwhile study.

\section{Concluding remarks}

Gautama Siddha was a scholar, a linguist and a historian. He stands high in the list of ancient Indian scholars who carried out the task of introducing ancient Indian scientific thought to the new land, thus enabling it to take root there and develop thereafter. It was not possible to translate Indian texts verbatim. Therefore the scholars studied corresponding Chinese systems and modified Indian material so as to make it digestible to the Chinese palate. Gautama was instrumental in the comparative study of two systems and their integration to some extent.

\section{ACKNOWLEDGEMENTS}

Thanks are due to the referees whose valuable suggestions led to an improved version of this paper.

\section{BIBLIOGRAPHY}

Al-Sīrāfì, Abū Zayd Ḥasan ibn Yazīd. 10th cen Sulayman al-Tajir, 10th cent, Ancient accounts of India and China, by two Mohammedan travellers, who went to those parts in the 9th century; tr. from the Arabic, by the late learned Eusebius Renaudot. With notes, illustrations and inquiries by the same hand, London, 1733 (online).
Cullen, Christopher. An eighth century Chinese table of tangents, Chinese Science, 5:1, 1982.

Deshpande, Vijaya Jayant. Indian influences on early Chinese ophthalmology: Glaucoma as a case study, in Bulletin of the School of Oriental and African Studies, 62/2, June 1999, pp.306-322.

Deshpande, Vijaya Jayant. Ophthalmic Surgery - A chapter in the history of Sino-Indian medical contacts - in Bulletin of the School of Oriental and African Studies, 63/3 (October 2000):370-88.

Deshpande, Vijaya Jayant with Fan Ka Wai. Restoring the Dragon's vision, Nagarjuna and Medieval Chinese Ophthalmology, published by Chinese Civilization Centre, City University of Hong Kong, Hong Kong, 2012.

Duan, Yao-Yong and Li, Wen-Lin. The Influence of Indian Trigonometry on Chinese Calendar-Calculations in the Tang Dynasty, B.S. Yadav and M. Mohan (eds.), Ancient Indian Leaps into Mathematics, 45, DOI 10.1007/978-0-8176-4695-0 3,_c Springer Science+Business Media, LLC 2011, pp 45-54.

Encyclopedia of India-China cultural contacts, Ma Xposure Media Group, New Delhi, 2014, part 1\&2

Ho Pengyoke. Li, Qi and Shu: An Introduction to Science and Civilization in China. Hong Kong University Press, Hong Kong, 1985.

Jean-Claude Martzloff- Le Calendrier Chinois. Webpage http://chinesereferenceshelf.brillonline.com/grandricci/files/calendrier-chinoi.pdf;jsessionid= 2357FC3C6BC11256CD5AE2895F2F9441

Kai yuan zhan jing 开元占经 by Gautama Siddha 㫿昙悉达, 九州出版社,: Jiuzhou book publishing house. Beijing, 2012.

Lu hui. Jiuzhi Calendar, Encyclopedia of India-China cultural contacts, MaXposure Media Group, New Delhi, 2014, part 1, p 82.

Li Hui and Niu Weixing. From Rāhu and Ketu to Four Invisible Bodies: An Example of the Sinicization of Foreign Astronomical Terminology. Journal of Shanghai Jiao Tong University (Philosophy and Social Sciences) 18:6 (2010).

Needham, Joseph and Wang Ling. Science and Civilization in China, Vol. 3 Mathematics and Sciences of the Heaven and Earth. Cambridge University Press, 1959.

\footnotetext{
${ }^{30}$ Li Hui and Niu Weixing (2014) p 96

Also see, Duan Yao-Yong and Li Wen-Lin (2011) p 45-54

${ }^{31}$ Lu hui (2014) part 1, p 82
} 
Niu, Weixing and Jiang Xiaoyun. On the noon shadow in Chinese translated sütras. Annals of Shanghai observatory, Academica Sinica, 19 (1998).

Niu weixing. Astronomy in the Sütras Translated into Chinese. Studies in History of Medicine and Science (New Delhi), XV, No.1-2, New Series(1997/98), 119129 (http://shc2000.sjtu.edu.cn/0406/astronomy.htm).

Niu Weixing. On the Brahmahorānavagraha as well as its Date and Authorship, History of Natural Sciences, 24.4(2005):329.

Sen, Tansen. Gautama Zhuan: an Indian Astronomer at the Tang court, China Report (http://chi.sagepub.com/) Sage Publications, 1995, 31:197.

Siku Quanshu 四庫全書Wen yuan ge si ku quan shu dian zi ban. [Catalog] [electronic resource] / Di zhi wen hua chu ban you xian gong si. 文淵閣四庫全書電子版 [Catalog] [electronic resource] / 迪志文化出版有限公司. Hong Kong [1999?].

Yabuuti, Kiyosi. 陏唐糜法史の研究 Researches on the history of calendrical sciences in the Sui and Tang dynasties, Tokyo Sanseido 三省堂 (1944).

Yabuuti, Kiyosi. The Chiuchih li-An Indian astronomical book in the Tang dynasty, in Yabuuti (ed) Chugoko chusei kagaku gijutsushi no kenkyu, Studies in the History of Science and Technology in Medieval China中国中世科学技术史 研究, Tokyo, Kadokawa shoten, 1963, pp. 493-538.

Yabuuti, Kiyosi. Researches on the Chiu-chih li (Jiuzhili) Indian Astronomy under the T'ang Dynasty. Acta Asiatica 36 (1979):7-48.

Yano, Michio. Yabuuti Kiyosi as a historian of exact sciences, EASTM 18, 2001. 